\title{
Concentration of Heavy Metals in the Soils near Some Mechanic Villages in Abeokuta Metropolis, Ogun State, Nigeria.
}

\author{
Olayinka, Olufunmilayo. $\mathrm{O}^{*}$ and Adedeji, Oludare $\mathrm{H}$. \\ Department of Environmental Management and Toxicology, Federal University of Agriculture, PMB 2240, \\ Abeokuta, Ogun State, Nigeria. \\ Corresponding Author: fummy2favour@yahoo.com.ph
}

\begin{abstract}
Soils and water bodies near auto mechanic village (MV) contain heavy metals, which pollute the environments and are hazardous to human and environmental health. Assessment of heavy metal concentration in three replicate soil and water samples from three MVs (Fajol, Id-Aba and Kotopo) in Abeokuta metropolis in Nigeria was conducted. Heavy metal concentrations in topsoil of the MVs showed copper ranging from $0.02 \mathrm{mgkg}^{-1}$ in the topsoil at Idi-Aba MV to $126.89 \mathrm{mgkg}$ ${ }^{1}$ for topsoil at Kotopo MV. The level of copper detected in Kotopo MV soil is however higher than the allowable limits for Sweden, Netherlands and Germany. Mean concentration of zinc in soils of the MVs were 2.89, 0.91 and 86.23 mgkg respectively for Fajol, Idi-Aba and Kotopo MV respectively. Metal enrichment factor indicated that the contamination degree ranged from unpolluted to moderately polluted areas. Copper is the most enriched metal in the soil of the MVs especially at Kotopo MV. Relative abundance of the metals in the topsoil $(0-15 \mathrm{~cm})$ in Fajol MV follow the order $\mathrm{Zn}>\mathrm{Ni}>\mathrm{Cr}$ $>\mathrm{Pb}>\mathrm{Cu}>\mathrm{Co}>\mathrm{Cd}$. For the Idi-Aba MV, relative abundance is in the order $\mathrm{Ni}>\mathrm{Zn}>\mathrm{Cr}>\mathrm{Pb}>\mathrm{Cu}>\mathrm{Co}$ and $\mathrm{Cd}$, and that of Kotopo MV was $\mathrm{Cu}>\mathrm{Zn}>\mathrm{Pb}>\mathrm{Ni}>\mathrm{Cr}$, Co and $\mathrm{Cd}$. Mean heavy metal in the water samples were lower than those found in the soils of the MVs. Stream water near the Kotopo MV had the highest concentration of most metals. Zinc had the highest mean concentration of $2.02 \mathrm{mgL}^{-1}$ while copper was $1.09 \mathrm{mgL}^{-1}$. There is an urgent need to put measures in place to monitor the activities in these MVs in order to safeguard peoples' health environmental integrity.
\end{abstract}

Keywords: Heavy metals; soil; soil pollution index; metal enrichment factor and water.

\section{Council for Innovative Research}

Peer Review Research Publishing System

Journal: Journal of Advances in Chemistry

Vol. 8, No. 3

editor@cirjac.com

www.jac.cirworld.com, member.cirworld.com 


\section{Introduction}

Worldwide and especially in developing countries, increasing population, urban expansion, economic development have resulted in increasing degradation of major natural resources such soil and water which pose challenges to environmental management and sustainable development [1]. Major cities in Nigeria like Lagos, Abuja, Ibadan and Abeokuta were been confronted with the problems of managing waste and pollution from increasing anthropogenic activities. Transportation related activities including the repair of automobiles in the so called mechanic villages (MV) have resulted in the concentration of heavy metals on soil and other environmental media like water bodies [2-6].. One of the major sources of increase heavy metal concentration of the ecosystem in Nigeria is the unwholesome activities of the automobile mechanics [7-8] such as the dumping of metal scraps, used oil, paints, carbide, battery acid and other toxic wastes. In many parts of Nigeria, mechanic villages (MV) were established on the outskirt of major towns and cities for the repair and service of vehicles because of lack of space and improper waste management which has serious environmental consequences [5, 9-10]. Many cities in developed parts of the world have legally established regulations for effective collection and proper disposal of different types of wastes. However, in Nigeria wastes from the mechanic villages including used oil, metal scraps and vehicular emission are carelessly deposited on the soils, vegetation and water bodies near mechanic villages [4, 11-12]. These wastes contain heavy metals such as $\mathrm{Pb}, \mathrm{Cd}, \mathrm{Cr}, \mathrm{Fe}, \mathrm{Mn}, \mathrm{Zn}$ and $\mathrm{Cu}$, which could be dangerous to environmental and human health [13]. [3], observed that used oil in soil could lead to the build-up of essential and non-essential elements in the soil and eventual translocation into the plant tissues. Heavy metal toxicity has an inhibitory effect on plants growth, enzymatic activity, photosynthetic activity and accumulation of other nutrient elements, and damages the root system [14]. Used engine oil or transmission fluid poured on the ground therefore enriches the soil with heavy metals, which can drain into both surface waterways and groundwater [4]. Figure 1 below shows the hypothetical model of wastes generation in mechanic villages [15].

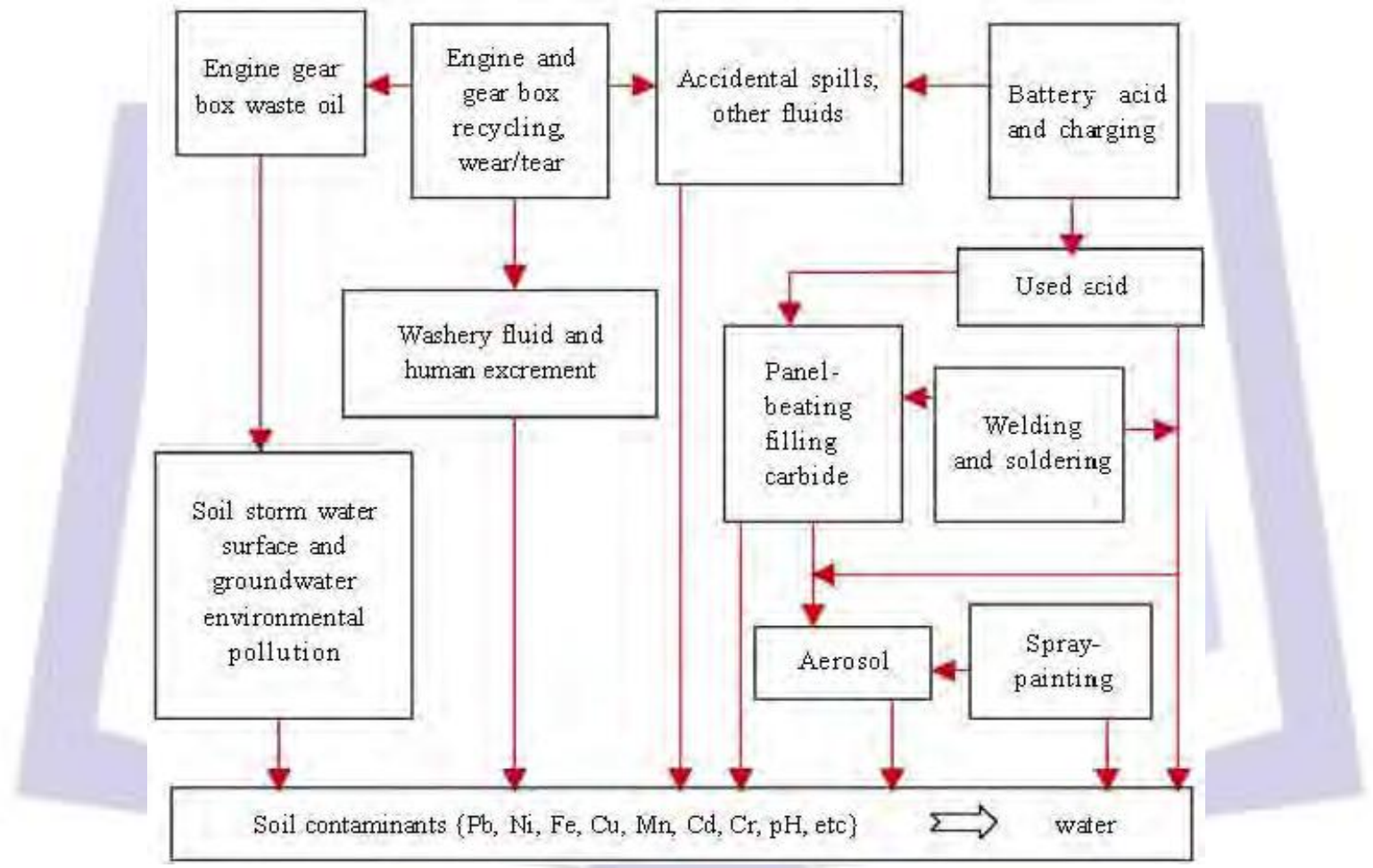

Figure 1: A hypothetical model of wastes generation in mechanic villages (Nwachukwu et al., 2010).

Furthermore, studies have shown that used oil is less viscous than unused oil, hence when disposed on the soil; it adsorbs to the soil particles, reduces porosity and therefore reduces aeration of soil [16]. Soil and water pollution problems associated with automobile mechanic wastes have been reported several studies [17-18]. Human health is negatively affected by consumption of crops grown on soils contaminated with heavy metals [19]. The non-biodegradable nature of heavy metals and their long biological half-life make them a critical environmental issue [13]. Therefore, there is need to determine the heavy metals in soil and water in the vicinity of the mechanic village as urban expansion have caused spread out to these erstwhile isolated mechanic villages. People living close by are potentially at risk through the drinking of water or consumption of crops grown in the soil in the area. The aim of this study was to determine the concentration of heavy metals in the soils and water near some mechanic villages in Abeokuta metropolis, Ogun State, Nigeria. The result of the study is expected to add to the base line data for future heavy metal pollution status of the area. 


\section{MATERIALS AND METHODS}

\subsection{Study Area}

Abeokuta is the major city and the capital of Ogun State, southwest Nigeria. It is approximately located between Latitude $7^{\circ} 9^{\prime}$ and $7^{\circ} 14^{\prime} \mathrm{N}$ and Longitude $3^{\circ} 26^{\prime}$ and $3^{\circ} 40^{\prime} \mathrm{E}$. (Figure 2). It is situated on the fringe of the lowland rainforest and the guinea savanna of Nigeria. Abeokuta is located at a relative distance of $100 \mathrm{~km}$ north Lagos and $70 \mathrm{~km}$ south of Ibadan with road connections to other major towns and cities such as ljebu-ode, Sango-Ota, llaro, Sagamu, Aiyetoro, Agabra and others. The climate conditions fall into two distinct seasons i.e. the harmattan season (November to March) and the raining season (April to October) interrupted by short August break. The rains reach its peak in the months of June and September. The mean annual rainfall is about $1590 \mathrm{~mm}$; with an average annual temperature is $27.5^{\circ} \mathrm{C}$. It has a population of about 561,056 inhabitants comprising 261,481males and 291,575 females [20]. It has a high population density of more than 500 persons per hectare. The population have continue to grow making the city to sprawl toward surrounding villages and smaller towns such as Ajebo, Osiele, Odeda, Imala, Aro to mention a few. The government established mechanic villages in some of these villages to reduce the pollution from the activities of mechanics in the city. However, urban development and growth have made the erstwhile isolated mechanic villages to be crowded by residential buildings. Migrant workers and civil servants working in various institutions and establishments have moved close to the mechanic villages and the people are now faced with the potential risk of contaminants release from the area. In this study, popular mechanic villages located at Idi-Aba, Obantoko (Fajol) and Kotopo were chosen as representatives of mechanic villages in Abeokuta.

\subsection{Soil Sampling}

The soil samples were collected at three (3) selected mechanic villages (MV) in Abeokuta, Ogun state namely; Idi-Aba, Kotopo and Fajol mechanic villages using stainless steel soil auger. Nine (9) soil samples were collected from the three mechanic villages at three different depths of $0-15 \mathrm{~cm}, 15-30 \mathrm{~cm}$, and $30-45 \mathrm{~cm}$ and were placed in polythene bags and transported to the laboratory.

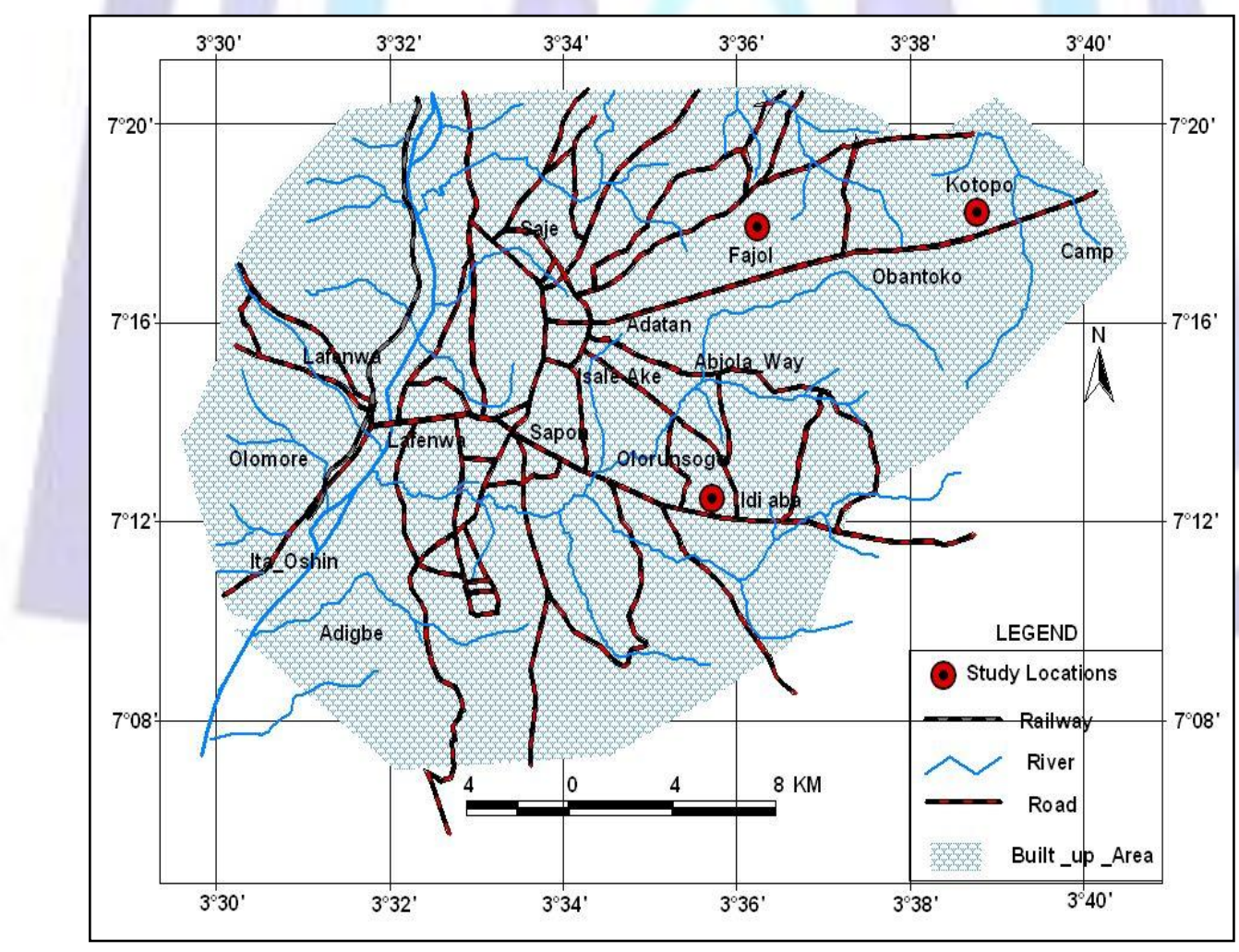

Figure 2: Map showing the area of study

\section{Soil preparation and analysis}

Soils used for the determination of Physico-chemical properties were air-dried at ambient temperature $\left(22-2^{\circ} \mathrm{C}\right)$. Crushed in a porcelain mortar, sieved through $2 \mathrm{~mm}$ sieve, and stored in plastic bottle prior analysis. Soil $\mathrm{pH}$ was determined according to [21], while particle size analysis was determined according to the method of [22] . The organic carbon content of soils was determined by the Walkey- Black and digestion method as described by [23], and then the 
organic matter content in the soils was determined by multiplying the organic carbon content from the procedure above by 1.742 using the assumption that organic matter content is approximately $58 \%$ carbon.

\subsection{Water sampling and analysis}

Water samples were collected from streams very close to Idi-Aba and Kotopo mechanic villages, while water samples was collected from the well around Fajol mechanic village. Water samples were collected in precleaned polypropylene screw capped bottles of one litre capacity. Samples collected were taken to the laboratory and water quality parameters like temperature; $\mathrm{pH}$, electrical conductivity (EC) and total dissolved solids (TDS) were determined immediately after collection. Other physicochemical parameters such as biochemical oxygen demand (BOD), chemical oxygen demand (COD), dissolved oxygen (DO), alkalinity, and chlorides were analysed within 36 hrs of collection following standards methods [24]. The $\mathrm{pH}$ of the sample was determined with the portable $\mathrm{pH}$ meter that has previously calibrated with buffer solution. Conductivity (EC) was measured with a conductivity meter calibrated with potassium chloride solution before the water samples were placed in ice chests and taken to the laboratory to determine other water quality parameters in accordance to standard methods [24]. Dissolved oxygen (DO) was determined by Winkler's titration. The dissolved oxygen contents of the water samples were fixed on the field by addition of manganous sulphate solution and alkali-iodide-azide reagents to the sample. The samples were transported to the laboratory where they were titrated with a standard sodium thiosulphate solution. Total dissolved solid was determined gravimetrically by evaporating a known volume of water sample to dryness in a pre-weighed crucible on a steam bath at $105^{\circ} \mathrm{C}$ Alkalinity and chloride were determined by titrimetric method. COD was determined titrimetrically with ferrous ammonium sulfate (FAS) after oxidation with the dichromate reflux method. To determine the BOD, $2 \mathrm{mls}$ of Manganese (II) sulphate was added to the water sample and immediately $2 \mathrm{mls}$ of alkali-iodide azide was added to the water solution. $2 \mathrm{mls}$ of Conc. $\mathrm{H}_{2} \mathrm{SO}_{4}$ was added to the water sample and the acid was allowed to rundown the neck of the bottle. It was re-stoppered and mixed by gentle inversion until the dissolution was completed. $203 \mathrm{ml}$ of the sample was decanted and measured into a conical flask and titrated against a $0.0125 \mathrm{M} . \mathrm{Na}_{2} \mathrm{~S}_{2} \mathrm{O}_{3} .5 \mathrm{H}_{2} \mathrm{O}$ (Thiosulphate solution).. $2 \mathrm{mls}$ of starch, solution was added to a straw pale colour and the colour becomes blue. The titration was continued by adding thiosulphate solution dropwise until the blue colour disappeared to become white or colourless.

\subsection{Heavy Metals Analysis}

Both soil and water samples were analyzed for $\mathrm{Cu}, \mathrm{Zn}, \mathrm{Co}, \mathrm{Cr}, \mathrm{Cd}, \mathrm{Pb}$ and Ni using a model 200A Buck Scientific Atomic Absorption Spectrophotometer according to the method of [25].

\subsection{Statistical Analysis}

Pearson Product Moment Correlation Coefficient (PPMCC) was used to find out correlations among the various metals. All analysis was carried out using the SPSS statistical package (Version 17).

\section{RESULT AND DISCUSSION}

Figure 3 below shows the particle size distribution of soils in the MVs and control site. The particle analysis of soil samples indicated that sand and silt contents, on an average, ranged from $72.20 \pm 3.05-82.85 \pm 2.35$ and $10.67 \pm 1.12-$ $14.67 \pm 2.35$. Table 1 shows the descriptive statistics of physico-chemical parameters in the soils of selected MVs and control site. The result showed organic matter (OM) decrease down the profile of soils taken from Fajol and Idi-Aba MVs. This implies that plant nutrition will decrease down the depth of the soil. Soil $\mathrm{pH}$ is an important property showing great effects on solute concentration and absorption in soil. Mean soil pH for Fajol, Idi-Aba and Kotopo ranged from 6.20-6.37, 6.33-6.43 and 6.59-6.67 respectively. These values were within the range reported by [26]. 


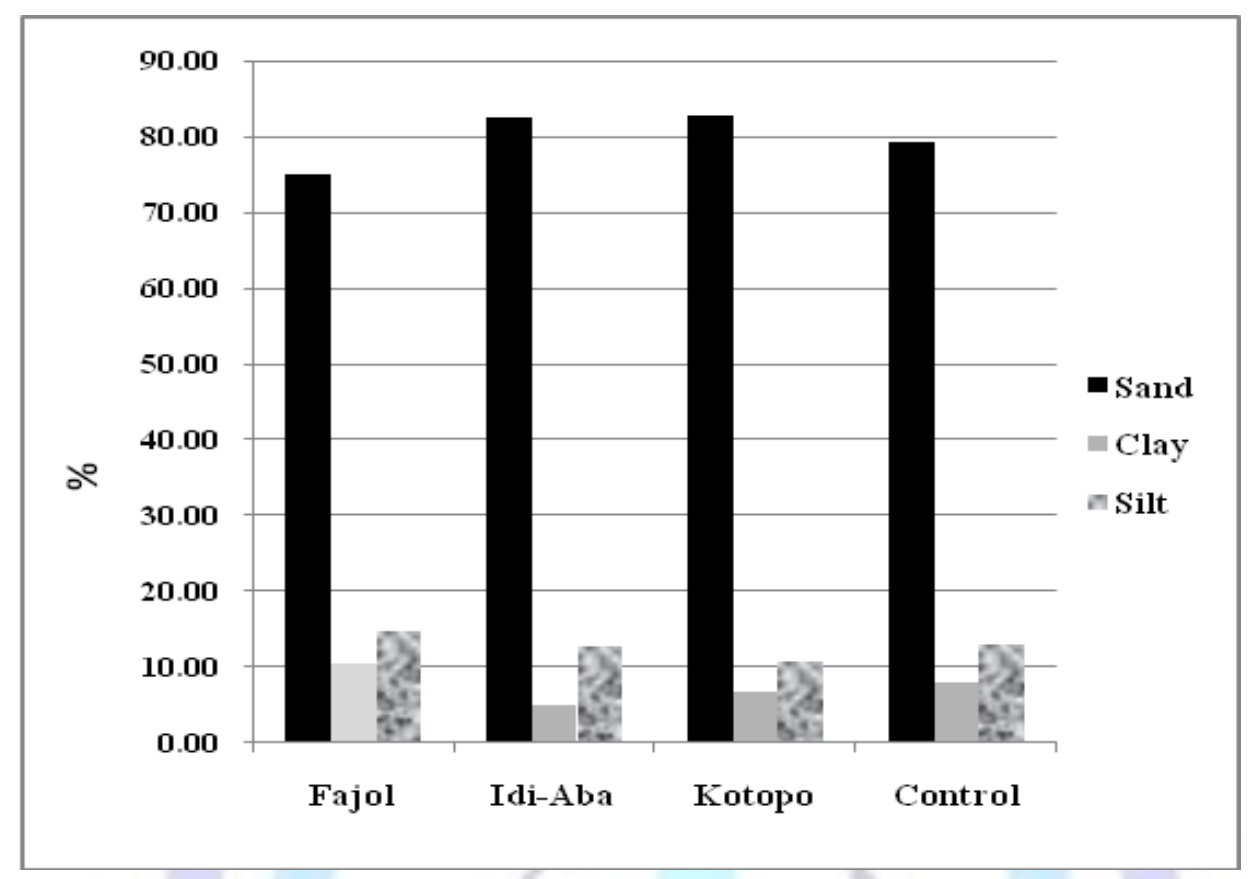

Figure 3: Particle size distribution of soils in the MVs and control site

Soil $\mathrm{pH}$ values decreased down the depth in both Fajol and Idi-Aba and this may be due to oil spills in the mechanic villages that make the soil to be acidic. However, soil pH increase in Kotopo soil with increasing depths. A decrease in soil $\mathrm{pH}$ increases the mobility of positively charged heavy metals because of proton competition with these metals and decrease in negative binding sites [27].

Table 1. Descriptive Statistics of Physico-chemical Parameters in the soils of selected MVs and Control site

\begin{tabular}{|c|c|c|c|c|c|c|c|c|c|}
\hline Fajol & $\begin{array}{l}\text { Temp. } \\
\left({ }^{\circ} \mathrm{C}\right)\end{array}$ & $\begin{array}{l}E C \\
(\mu S c m)\end{array}$ & $\begin{array}{l}O M \\
\%\end{array}$ & $p H$ & Kotopo & $\begin{array}{c}\text { Temp. } \\
\left({ }^{\circ} \mathrm{C}\right)\end{array}$ & $\begin{array}{c}E C \\
(\mu S c m\end{array}$ & $\begin{array}{l}O M \\
\%\end{array}$ & $p H$ \\
\hline Mean & 28.73 & 377.00 & 2.34 & 6.30 & Mean & 28.83 & 94.50 & 2.99 & 6.63 \\
\hline Median & 28.75 & 341.00 & 1.88 & 6.32 & Median & 28.85 & 90.50 & 3.20 & 6.62 \\
\hline Standard Dev. & 0.08 & 194.02 & 1.15 & 0.09 & Standard Dev. & 0.08 & 12.01 & 0.81 & 0.04 \\
\hline Range & 0.15 & 383.00 & 2.16 & 0.17 & Range & 0.15 & 23.00 & 1.59 & 0.08 \\
\hline Minimum & 28.65 & 203.50 & 1.49 & 6.20 & Minimum & 28.75 & 85.00 & 2.09 & 6.59 \\
\hline Maximum & 28.80 & 586.50 & 3.65 & 6.37 & Maximum & 28.90 & 108.00 & 3.67 & 6.67 \\
\hline \multicolumn{5}{|l|}{ Idi-Aba } & \multicolumn{5}{|l|}{ Control } \\
\hline Mean & 38.02 & 122.17 & 2.31 & 6.44 & Mean & 28.70 & 72.05 & 1.16 & 7.32 \\
\hline Median & 28.85 & 122.50 & 2.71 & 6.43 & Median & 28.70 & 75.25 & 1.18 & 7.21 \\
\hline Standard Dev. & 15.92 & 2.52 & 0.80 & 0.12 & Standard Dev. & 0.10 & 20.24 & 0.38 & 0.29 \\
\hline Range & 27.60 & 5.00 & 1.43 & 0.24 & Range & 0.20 & 40.10 & 0.76 & 0.55 \\
\hline Minimum & 28.80 & 119.50 & 1.39 & 6.33 & Minimum & 28.60 & 50.40 & 0.77 & 7.10 \\
\hline Maximum & 56.40 & 124.50 & 2.82 & 6.57 & Maximum & 28.80 & 90.50 & 1.53 & 7.65 \\
\hline
\end{tabular}

The soil electrical conductivity (EC) and total dissolved solid (TDS) of the three locations decreased with depths (Table 2). The mean \pm standard deviation of the soil electrical conductivity in the mechanic villages ranged from $94.58 \pm$ $4.40-377.00 \pm 70.85 \mu \mathrm{s} / \mathrm{cm}$, while average TDS ranged from $46.83 \pm 2.17-186.67 \pm 35.81$. Fajol soil had the highest value of EC (Table 2). There is linear relationship between EC and TDS, which might due to increase in concentration of soluble salts in the soil. EC and TDS of Fajol soil were significantly different from Idi-Aba and Kotopo soils $(p<0.05)$. 


\subsection{Heavy Metals Concentrations in Soils}

Table 2 shows the descriptive statistics of heavy metals concentrations in the soils of the mechanic villages (MVs). In many instances, highest concentrations of heavy metals were at the topsoil $(0-15 \mathrm{~cm})$ and decreased with depths to the subsoil $(15-30 \mathrm{~cm})$. Heavy metal concentrations in topsoil of the MV showed copper ranging from $0.02 \mathrm{mgkg}-$ ${ }^{1}$ at Idi-Aba MV to 126.89 mgkg-1 at Kotopo MV (Table 3). Highest concentration copper in the soil taken from Idi-Aba MV was $0.47 \mathrm{mgkg}^{-1}$ at the $15-30 \mathrm{~cm}$ soil depth. It might be due to downward movement of the metal. The high Cu levels in the soils of the mechanic villages in this study are attributing to the improper disposal of waste lubricants and metal scarps. Elevated value of copper in Kotopo MV soil is also traceable to the fact that the MV is older and larger than the two other MVs. More activities takes place in this MV where different materials such as copper conductors and wires, tubes, solders and myriads of other maintenance items made from copper are dumped indiscriminately on the soil. The level of copper determined in this study was below the allowable limits except for Kotopo MV soil, which was higher than the allowable limits for Sweden, Netherlands and Germany.

In related studies, Abdu [16] reported soil copper concentration of $0.8-18 \mathrm{mgkg}-1$ in a study conducted on urban soils in Kano, Nigeria; while[11] estimated copper pollution of $204.33-273.83 \mu \mathrm{g} / \mathrm{g}$ in the soil of auto mechanic workshop in Makurdi,, Nigeria. [28] have reported that copper, chromium (III) and (VI) inhibit the activity of soil enzymes like dehydrogenase, urease acid phosphatase and alkaline phosphatise.

Table 2: Descriptive statistics of metal concentration in the soils of the selected mechanic villages around Abeokuta metropolis.

\begin{tabular}{|c|c|c|c|c|c|c|c|}
\hline Fajol & Cd & Co & $\mathrm{Cr}$ & $\mathrm{Cu}$ & $\mathrm{Ni}$ & $\mathrm{Pb}$ & Zn \\
\hline Mean & 0.05 & 0.06 & 1.58 & 0.87 & 2.26 & 0.77 & 2.88 \\
\hline Median & 0.04 & 0.05 & 1.52 & 0.89 & 2.09 & 1.08 & 2.74 \\
\hline Standard Deviation & 0.02 & 0.02 & 0.10 & 0.06 & 0.29 & 0.64 & 0.80 \\
\hline Range & 0.04 & 0.04 & 0.18 & 0.11 & 0.50 & 1.16 & 1.59 \\
\hline Minimum & 0.04 & 0.04 & 1.52 & 0.80 & 2.09 & 0.04 & 2.16 \\
\hline Maximum & 0.08 & 0.08 & 1.70 & 0.91 & 2.59 & 1.20 & 3.75 \\
\hline \multicolumn{8}{|l|}{ Idi-Aba } \\
\hline Mean & 0.07 & 0.07 & 0.87 & 0.37 & 1.41 & 1.79 & 1.17 \\
\hline Median & 0.08 & 0.08 & 1.03 & 0.43 & 1.75 & 0.80 & 0.99 \\
\hline Standard Deviation & 0.02 & 0.02 & 0.41 & 0.15 & 0.89 & 1.74 & 0.49 \\
\hline Range & 0.04 & 0.04 & 0.78 & 0.27 & 1.68 & 3.04 & 0.93 \\
\hline Minimum & 0.04 & 0.04 & 0.40 & 0.20 & 0.40 & 0.76 & 0.80 \\
\hline Maximum & 0.08 & 0.08 & 1.18 & 0.47 & 2.08 & 3.80 & 1.73 \\
\hline \multicolumn{8}{|l|}{ Kotopo } \\
\hline Mean & 0.05 & 0.05 & 0.65 & 67.92 & 2.66 & 12.76 & 86.20 \\
\hline Median & 0.04 & 0.04 & 0.76 & 40.14 & 2.65 & 11.60 & 98.28 \\
\hline Standard Deviation & 0.02 & 0.02 & 0.22 & 51.10 & 0.14 & 3.53 & 31.45 \\
\hline Range & 0.04 & 0.04 & 0.40 & 90.17 & 0.28 & 6.76 & 59.33 \\
\hline Minimum & 0.04 & 0.04 & 0.40 & 36.72 & 2.53 & 9.96 & 50.50 \\
\hline Maximum & 0.08 & 0.08 & 0.80 & 126.89 & 2.81 & 16.72 & 109.83 \\
\hline
\end{tabular}

[29] reported that when copper ends up in soils, it strongly attaches to organic matter and minerals. As a result, it does not travel very far after release. Perhaps this explains why the highest values of copper recorded on most of the locations were in the $0-15 \mathrm{~cm}^{3}$ depths (Figure 4). 

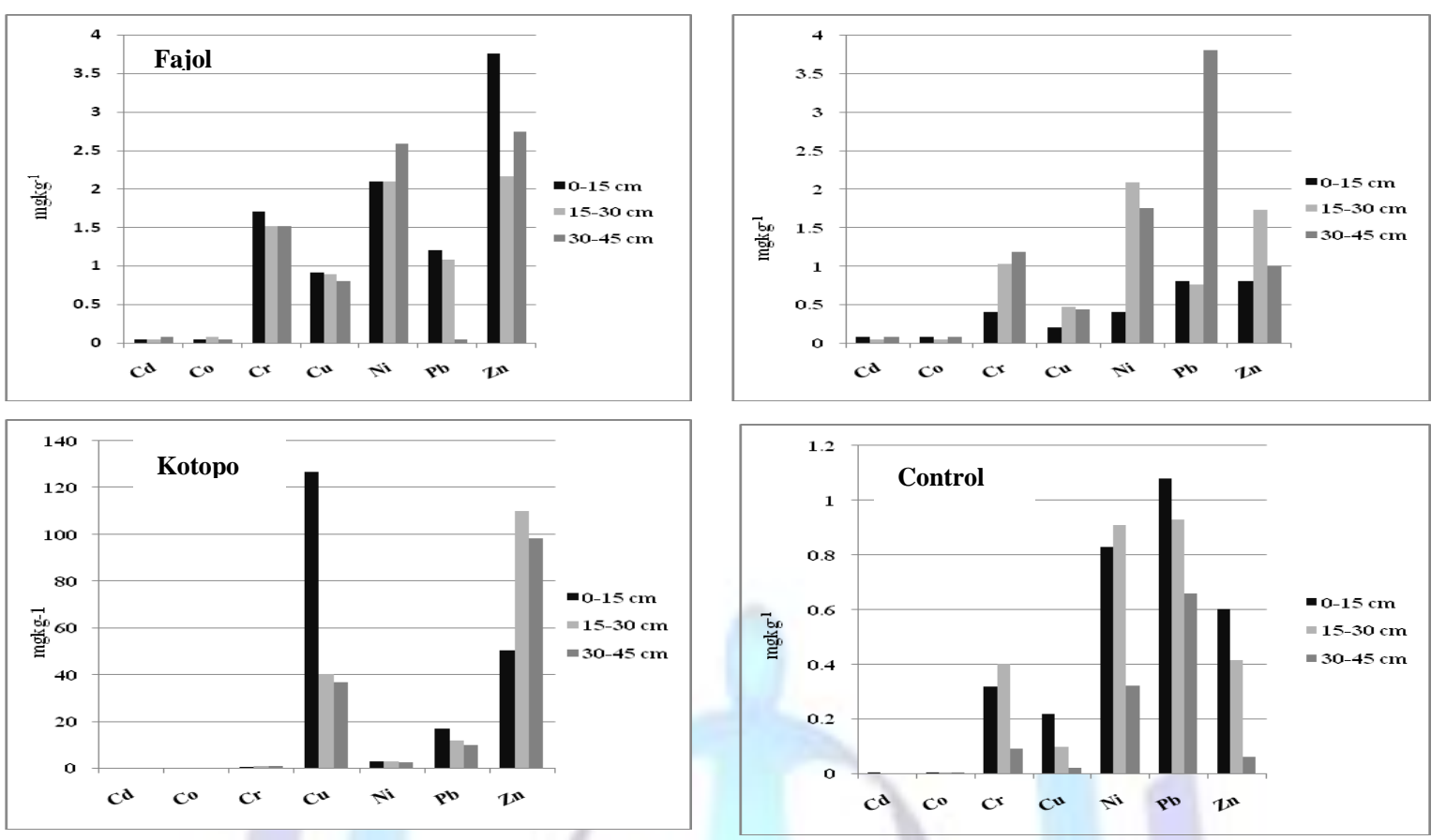

Figure 4: Heavy metal concentration in different soil layers in the selected MVs in Abeokuta Metropolis

The average concentration of zinc followed the same trend as copper. Zinc concentration in the soils of the MVs ranged from $0.08 \mathrm{mgkg}-1$ in the topsoil at Idi-Aba MV to $109.83 \mathrm{mgkg}-1$ in the $15-30 \mathrm{~cm}$ layer for Kotopo MV (Figure 3). Mean concentration of zinc in soils of the MVs were $2.89,0.91$ and $86.23 \mathrm{mgkg}^{-1}$ respectively for Fajol, Idi-Aba and Kotopo MV respectively (Table 2). High concentration of zinc found in the Kotopo MV soil might be due to the large volume of used engine oil dumped on the soil. $\mathrm{Zn}$ had the highest average concentration of all the heavy metal in all the locations but this is quite lower than the allowable limits [30]. Zinc did not decrease vertically with soil depth and this disagrees with [31]. Odoh et al. [11] reported zinc concentration level of between and $106.67-138.33 \mu \mathrm{g} / \mathrm{g}$ for auto mechanic workshop in Makurdi. Furthermore, [18] reported zinc concentration of $703 \mathrm{mgkg}^{-1}$ and $423 \mathrm{mgkg}^{-1}$ for topsoil and subsoil respectively in soils near a lubricating Oil Producing Factory, Koko, Nigeria. Zinc in concentrated level can be harmful in plants and it can cause stunt plant growth [32]. Concentrations of lead $(\mathrm{Pb})$ in the soil of the MVs ranged between $0.0-16.72 \mathrm{mgkg}^{-1}$ (Table 3). Except for the Idi-Aba MV, lead is concentrated in the topsoils with mean concentration of between $0.77-12.76$ $\mathrm{mgkg}^{-1}$ in Fajol to Kotopo MVs. This higher retention of lead in the top layers of the soils corroborates the finding of [33], which stated that lead is especially prone to accumulation in surface horizons of soil because its low water solubility results in very low mobility. Although, [34] observed that lead accumulation in the topsoil of Nigerian soil is due to longterm cultivation; [35] however, reported that sesquioxides the major soil components contribute to heavy metal fractions in the soil environment. The values of lead obtained in this study were all significantly lower than the $1162 \mathrm{mgkg}^{-1} \mathrm{reported}^{-1}$ by [15] and the $501.58 \mathrm{mgkg}^{-1}$ reported by [36] in their studies in different parts of Nigeria. The level of lead determined in MV soils in this study were lower than the international allowable limits in other countries of the world [30] in spite of the fact that the three MVs were areas wastes such as gasoline, used engine oil, diesel and petrochemicals are release into the soil. Allowable limits of lead in the soil ranged between $40-300 \mathrm{mgkg}^{-1}$ for countries like the United Kingdom, Luxemburg, Austria, Germany, France, the Netherlands and Sweden [30]. [37] stated that soil Pb concentrations greater than 1.0 mgkg-1 generally indicate a local source of pollution. It is worth mentioning that there may be health concerns about $\mathrm{Pb}$ concentrations in auto-mechanical workshop soils when the levels rise above $500 \mu \mathrm{g} / \mathrm{g}$ because such areas are now residential buildings where children play about freely.

Average concentrations of cobalt $(\mathrm{Co})$ were consistently low at all sampling locations as compared to the other heavy metals. It ranged from Fajol to Kotopo as $0.05-0.07 \mathrm{mgkg}^{-1}$ respectively (Table 4). ). In Fajol, the highest value of nickel was found in the $30-45 \mathrm{~cm}$ depth of the soil, while in Idi-Aba and Kotopo the highest values were found in $15-30 \mathrm{~cm}$ depths. Odoh et al.[11] reported cobalt concentration of $2.07-2.93 \mu \mathrm{g} / \mathrm{g}$ in the soils of auto mechanic workshop in Makurdi. Nickel (Ni) showed a range of $0.04-2.81 \mathrm{mgkg}^{-1}$ at all depths in all locations. This result agrees with Lenntech [29] who reported that the nickel content in soil could be as low as $0.2 \mathrm{mgkg}^{-1}$ or high as $450 \mathrm{mgkg}^{-1}$. The maximum value of nickel in this study was below the limit set for most European countries [30]. Nickel accumulates in plant and uptake of too large nick from plants grown on nickel-rich soil can result into cancers of the lung, nose, birth defects and heart disorders in human that consume such plants [29]. Nickel concentrations might be due to the disposal of spent automobile batteries from the nearby auto-battery charger and various paint wastes and pigments, which have contributed to the contamination of the soil [36]. The highest concentration of chromium $\left(1.18 \mathrm{mgkg}^{-1}\right)$ was found in the $30-45 \mathrm{~cm}$ soil layer at Idi-Aba MV and lowest $0.04 \mathrm{mgkg}^{-1}$ in the topsoil $(0-15 \mathrm{~cm})$ at Kotopo MV. Except for Fajol MV, chromium content increases as we go down the soil profile (Table 3) with mean concentration of $0.26-1.58 \mathrm{mgkg}^{-1}$. Chromium levels determined in the soils of the MVs were all below the allowable levels set by most countries [30]. Although there is no risk of chromium contamination on a global scale, local permeation of the metal to soil, water or the atmosphere might result in excessive amount of this pollutants in bio-geochemical circulation [38]. [39] reported that non- biodegradability of 
chromium is responsible for is persistence in the environment, once mixed in soil; it undergoes transformation into various mobile forms before ending into the environmental sink.

Average concentration of cadmium $(\mathrm{Cd})$ in this study ranged between $0.04-0.08 \mathrm{mgkg}^{-1}$ which is not significantly different (Table 3). The low concentration of this metal in soil might be due to its mobility in soil systems others investigated. The presence of only trace amounts of cadmium in all depths indicates negligible leaching to lower soils horizons and little risk of groundwater contamination [40]. The mean Cd concentration determined in this study was relatively low compared to that of [1]. Who investigated heavy metals in soils of auto-mechanic shops and refuse dump sites in Makurdi, Nigeria and reported a range of $0.6-3.5 \mathrm{mgkg}^{-1}$. The average cadmium concentration of $0.05 \pm 0.00$ $\mathrm{mgkg}^{-1}$ obtained in the soil samples of MVs in this study was lower than the limits of $\mathrm{n} 0.5-3 \mathrm{mgkg}^{-1}$ in the soil for European countries [30]. However, enhanced level of cadmium could be due to the motor vehicle repairs such as bodywork, painting, soldering, brake fluid, engine oils, and corrosion of metal, batteries and metal parts such as radiators and indiscriminate dumping of waste products on the soil [41]. Long exposure to that trace amount present might result in kidney damage and cardiovascular problems. High concentration of $\mathrm{Cu}, \mathrm{Zn}$, and $\mathrm{Pb}$ and may be associated with nature of activities in the sampling locations i.e. the auto-mechanical workshops. The concentrations of all the heavy metals determined in the soils of the mechanic villages compared to control may be due to contamination by automobile emissions, engine oil and lubricants, metal scraps that are been deposited on the land over a period of time. Researchers have stated that the degree of heavy metal pollution in urban areas varied according to location [2]. It should be noted that mobility and availability of heavy metals in soils depend on how the metals are associated with the components of the soil, and the measure of the mobility and availability of metals serves to predict the behaviour of heavy metals in the soil [42] There are significant $(p<0.05)$ correlations among the mean concentration of metals found in the soils of the MVs in the study area (Table 5). For instance, cadmium concentration in the soils of the MVs is significantly but negatively $(p<0.05)$ correlated with all other metals except for the significant positive correlation with copper (0.97). Correlations between copper and other metals like nickel, lead and zinc were significantly and positively high (Table 5) indicating close relation in the occurrence of these metals in the soils of the MVs.

Table 3: Correlations between different heavy metals in the soils of the selected MVs

\begin{tabular}{cccccccc}
\multicolumn{7}{c}{ in Abeokuta Metropolis. } \\
\hline $\mathbf{C d}$ & $\mathbf{C d}$ & $\mathbf{C o}$ & $\mathbf{C r}$ & $\mathbf{C u}$ & $\mathbf{N i}$ & $\mathbf{P b}$ & $\mathbf{Z n}$ \\
\hline $\mathbf{C o}$ & 1.00 & & & & & \\
$\mathbf{C r}$ & $-0.97^{*}$ & 1.00 & & & & \\
$\mathbf{C u}$ & $-0.51^{*}$ & $-0.70^{*}$ & $-0.68^{*}$ & 1.00 & & \\
$\mathbf{N i}$ & $-0.95^{*}$ & $-0.98^{*}$ & -0.03 & $0.75^{*}$ & 1.00 & \\
$\mathbf{P b}$ & -0.43 & $-0.64^{*}$ & $-0.73^{*}$ & $1.00^{*}$ & $0.70^{*}$ & 1.00 & \\
$\mathbf{Z n}$ & $-0.52^{*}$ & $-0.71^{*}$ & $-0.67^{*}$ & $1.00^{*}$ & $0.76^{*}$ & $1.00^{*}$ & 1.00 \\
\hline
\end{tabular}

Note: " Indicate correlations at 0.05 level of significance.

\section{2. $\quad$ Assessment of the Environmental Quality for Soils.}

It is important to know the impact(naturally and anthropogenically) of heavy metals in the soil [43]. To do this a geochemical normalization of the heavy metals data to a conservative element, such as Al, Fe, and Si have being employed [44-45]. Fe have been use successfully to normalize heavy metals contaminants by several authors [46]. The metal enrichment factor (EF) is defined as follows (Equation 1):

$$
E F=\frac{\left(\frac{M}{F \theta}\right) \text { sample }}{\left(\frac{M}{F \theta}\right) \text { packground }}
$$

Where EF is the enrichment factor, (M/ Fe) sample is the ratio of metal and Fe concentration of the sample and $(\mathrm{M} / \mathrm{Fe})$ background is the ratio of metals and Fe concentration of a background. The background concentrations of metals were taken from soils from an undisturbed area. An EF > 1.5 suggests that a significant proportion of trace metals is delivered by anthropogenic activities (non-crustal materials) [47], while EF values $<2$ suggest minimal metal enrichment and values $>2$ suggest various degrees of metal enrichments [47]. 


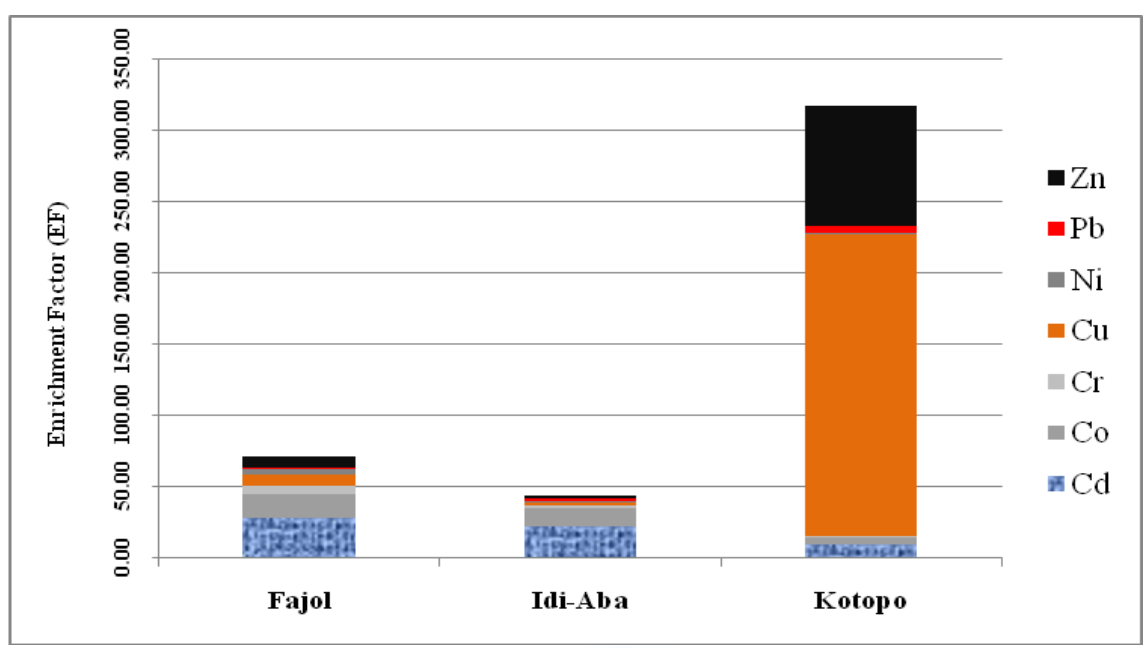

Figure 4: Enrichment Factor of MV soils in Abeokuta Metropolis

There are variation in the concentration of $\mathrm{Fe}$ in the soil in this study, however, mean concentrations of Fe in the soils of the MVs and the control site are 14,407, 22, 649, 43, 289 and 15,142 mgkg $^{-1}$ for Fajol, Idi-Aba, Kotopo and control site respectively. From the analysis of the enrichment factor, except for lead in Fajol MV, all other metals are highly enriched in the soil with enrichment factor (EF) ranging from 3.45 to 28.03 . Copper is the most enriched metal in the soil of the MVs especially at Kotopo (Figure 5). Kotopo MV soil is the most polluted with the heavy metals except for nickel with EF of 1.36 suggesting minimal metal enrichment. Idi-Aba MV has low EF for most of the metals except cadmium and cobalt, which are 22.29 and 12.16 suggesting significant anthropogenic pollution. On the average, enrichment factor (EF) of the heavy metals in the MVs' soils showed that Cd (28.03), Co (16.24), Cr (6.14), and Zn (8.43) had quite high enrichment in the Fajol MV (Figure 4). Pb, which was 0.91 and 1.34 for Fajol and Idi-Aba respectively, had minimal enrichment. It is worth noting that both copper and zinc has very high EF suggesting high level of metal enrichment in the soils. It also indicates that significant proportion of heavy metals investigated was released due to anthropogenic activities in the area [48]. Generally, the result shows that as EF values increase, the contributions of the anthropogenic origins also increase. Relative abundance of the metals in the topsoil $(0-15 \mathrm{~cm})$ in Fajol MV follow the order $\mathrm{Zn}>\mathrm{Ni}>\mathrm{Cr}>\mathrm{Pb}>\mathrm{Cu}>$ $\mathrm{Co}>\mathrm{Cd}$. For the Idi-Aba MV, relative abundance is in the order $\mathrm{Ni}>\mathrm{Zn}>\mathrm{Cr}>\mathrm{Pb}>\mathrm{Cu}>\mathrm{Co}$ and $\mathrm{Cd}$, and that of Kotopo $\mathrm{MV}$ was $\mathrm{Cu}>\mathrm{Zn}>\mathrm{Pb}>\mathrm{Ni}>\mathrm{Cr}$, Co and $\mathrm{Cd}$ (Table 3).

\subsection{Pollution of Water near MVs}

Means and concentrations of the various parameters analyzed on waters from the streams and well that were close to the selected MVs are shown in figure 5 below. The $\mathrm{pH}$ of the stream and well water were generally high which may have caused heavy metal precipitation to the bottom sediments. The $\mathrm{pH}$ of Fajol and Idi-Aba were still within WHO standard while, Kotopo $\mathrm{pH}$ was slightly higher than the standard that may hinder the metal availability in water. $\mathrm{pH}$ of the three different locations were significantly different from each other

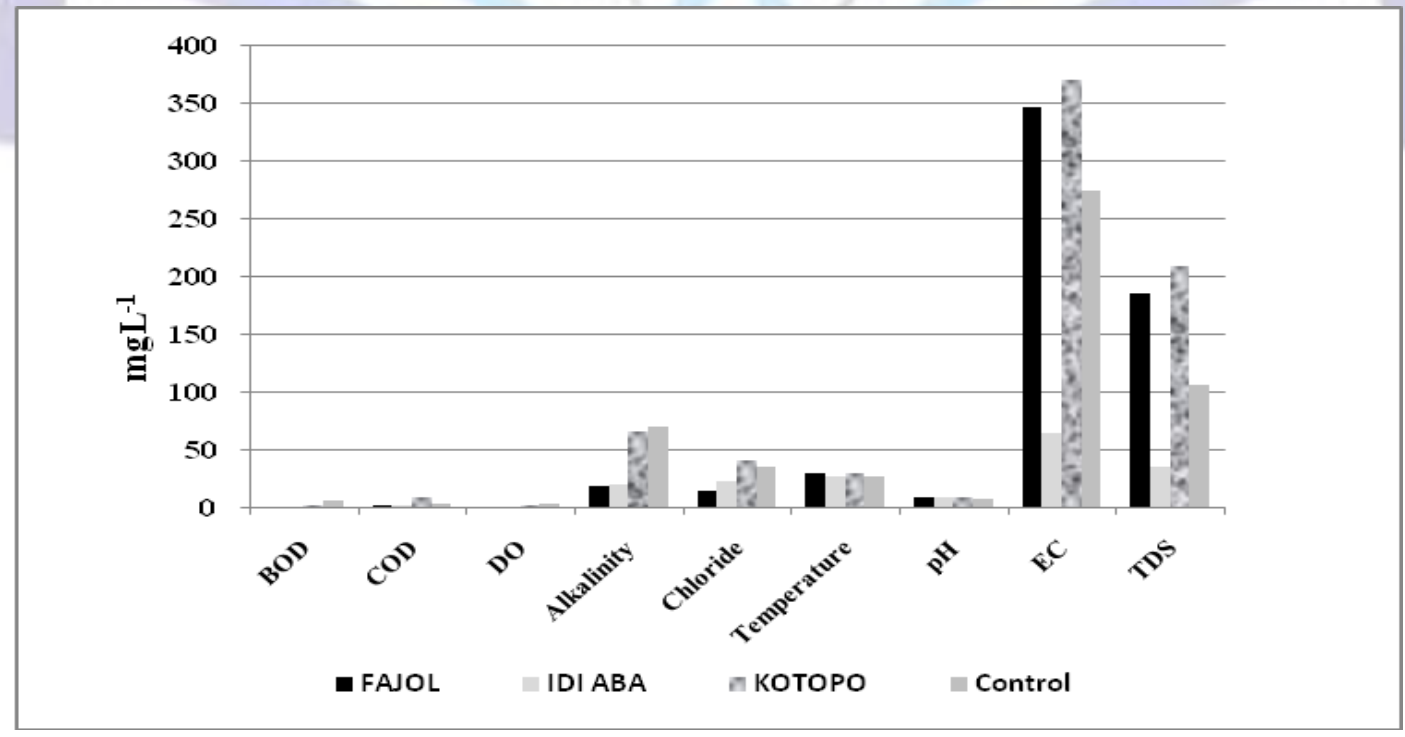

Figure 6: Physico-chemical parameters of water samples within the vicinity of the selected MVs in Abeokuta Metropolis. 
Temperatures of the three different locations were within the permissible level of WHO standard for drinking water [49]. Statistical comparison of temperature values of steam and well showed significant differences at $p<0.05$. Water temperature from stream near Idi-Aba MV was significantly different from Fajol and Kotopo MVs. Biochemical oxygen demand (BOD) and chemical oxygen demand (COD) values for the three MVs were far below the standard and no significant difference. Dissolved oxygen (DO) values ranged from 0.56 to $1.76 \mathrm{mgL}^{-1}$ for the MVs; while mean DO for the control was 5.09. Low DO values give an indication of water pollution around the MVs. BOD ranges from $0.56 \mathrm{mgL}^{-1}$ in the well water near Fajol MV to $1.76 \mathrm{mgL}^{-1}$ in the stream water near Kotopo MV (Figure 6). These values were low when compared to the $5.09 \mathrm{mgL}^{-1}$ for the control. Low BOD and the COD that ranged between 1.33 to $8.45 \mathrm{mgL}^{-1}$ indicate the low organic strength; water contaminants in the area are mostly from the MVs. Findings from this study showed that COD values for the water samples taken from the stream near Kotopo MV were higher than the permissible limit of $5 \mathrm{mgL}{ }^{1}$ for drinking water [49]. This means that the stream water was highly polluted with the chemicals leached away from waste in the MVs. Alkalinity of the water samples near the selected MVs were below the permissible limit with the average value of $34.33 \mathrm{mgL}^{-1}$. Alkalinity ranges from $18 \mathrm{mgL}^{-1}$ in the well water near Fajol MV to $65 \mathrm{mgL}^{-1}$ for stream water near Kotopo MV. Studies have shown that high alkalinity imparts an unpleasant taste, and may be deleterious to human health with high $\mathrm{pH}$, TDS and total hardness. Chloride, an anion often present in natural water has a significant concentration in sampled waters. It ranges from $13 \mathrm{mgL}^{-1}$ in the well water near Fajol MV to $40.5 \mathrm{mgL}^{-1}$ in the stream water near Kotopo MV (Figure 6). Alkalinity and chloride concentrations in the sampled well and stream waters were generally below the WHO standard [49]. Mean heavy metal in the water samples were lower than those found in the soils of the MVs do. Stream water near the Kotopo MV had the highest concentration of most metals. Zinc had the highest mean concentration of $2.02 \mathrm{mgL}^{-1}$ while copper was $1.09 \mathrm{mgL}^{-1}$ (Figure 7).

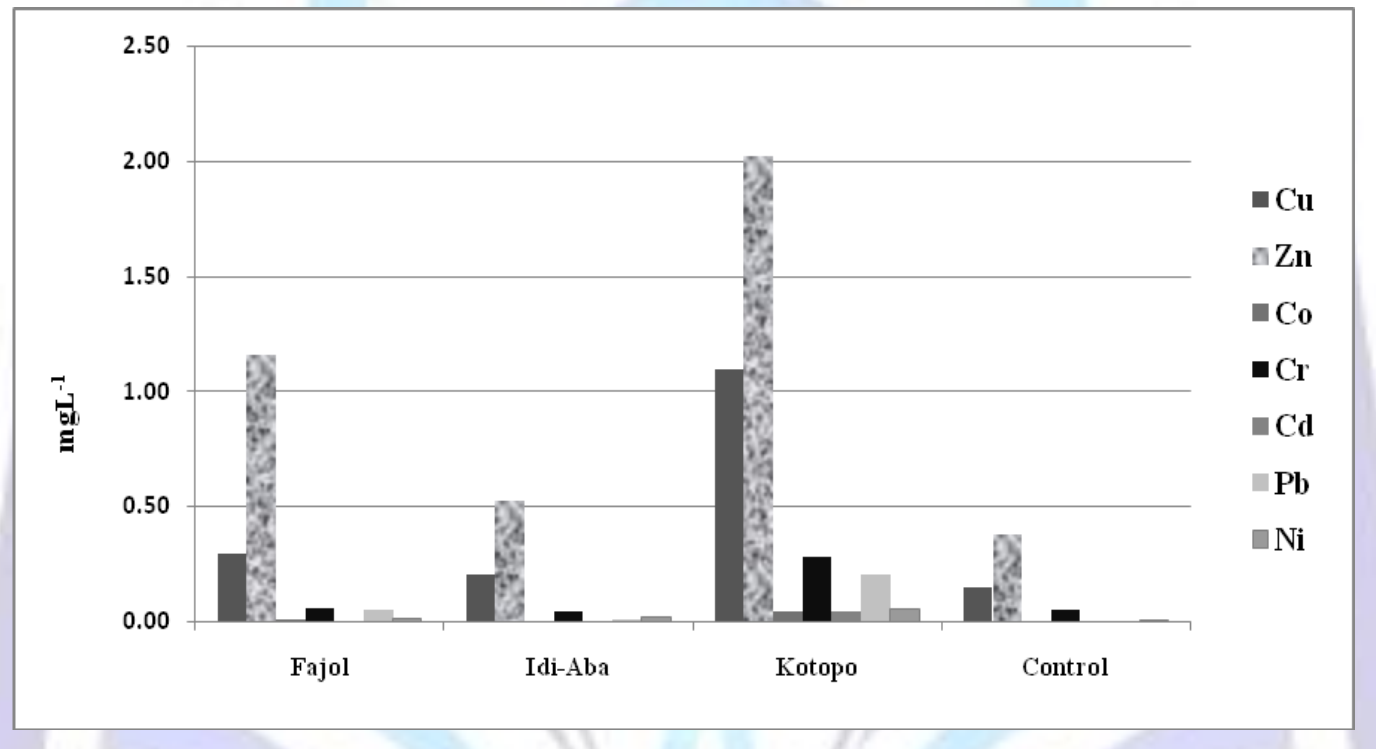

Figure 7: Heavy metal concentration in stream and well water samples near selected MVs in

\section{Abeokuta Metrpolis}

$\mathrm{Zn}$ values were below the permissible limit and it could be that there is bioaccumulation by organisms and adsorption of $\mathrm{Zn}$ by bottom sediments of the stream. Idi-Aba has the lowest concentration of most metals probably because the MV is not as old as the other MVs.

\section{CONCLUSION}

The concentrations of heavy metals determined from soil of the three different mechanic villages showed that the heavy metals were below the permissible levels but accumulation of these heavy metals with time will contaminate the soil, affect plant, and through food chain gets to human being. The enrichment factor analysis showed that metal pollution across the mechanic villages has significant spatial variation with respect to depths. There should be continuous environmental pollution monitoring from the mechanic villages to check heavy metal hazards. Environmental protection agencies should focus on conservation of soil and water and the inhabitant of such areas. 


\section{REFERENCES}

[1] Luter, L., Akaahan T.J., S. Attah, 2011. Heavy Metals in Soils of auto- mechanic shops and refuse dumpsites in Makurdi, Nigeria. J. Appl. Sci. Environ. Manage. Vol. 15(1), 207-210.

[2] Onianwa, P. C.; Jaiyeola, O. M.; Ezekenze, R. N. 2001. Heavy metal contamination of topsoil in the vicinities of autorepair workshops, gas stations and motor parks in a Nigerian city Toxicol. Environ. Chem., 84 (1-4), 33-39 http://dx.doi.org/10.1080/02772240309820

[3] Vwioko, D.E., Anoliefo, G.O., Fashemi, S.D. 2006. Metal contamination in plant tissues of Ricinus communis L. (Castor Oil) grown in Soil contaminated with spent lubricating oil. J. Appl. Sci. Environ. Manage, 10(3), 127 - 134.

[4[ Nwachukwu, M.A., Feng, H., Achilike, K. 2010a. Integrated study for Automobile wastes Management and Environmentally Friendly Mechanic Villages in the Imo River Basin, Nigeria African Journal of Environmental Science Technology, 4(4), 234-249, Available online at www.academicjournals.org/AJEST.

[5] Najib, N.W., Mohammed, S. A. Ismail, S.H., Wan Ahmad, A. A. 2012. Assessment of Heavy Metal in Soil due to Human Activities in Kangar, Perlis, Malaysia. International Journal of Civil \& Environmental Engineering IJCEE-IJENS Vol: 12 No: 06, 28-33

[6] Ra, K., Kim, E.-S., Kim, K.-T., Kim, J.-K., Lee, J.-M., and Choi, J.-Y., 2013. Assessment of heavy metal contamination and its ecological risk in the surface sediments along the coast of Korea. In: Conley, D.C., Masselink, G., Russell, P.E. and O'Hare, T.J. (eds.), Proceedings 12th International Coastal Symposium (Plymouth, England), Journal of Coastal Research, Special Issue No. 65, pp. 105-110

[7] Olayiwola, O. A. 2011. An assessment of soil heavy metal pollution by various allied artisans in auto-mechanic workshop in Osun State, Nigeria. EJEAFChe, 10 (2), 1881- 1886.

[8] Udebuani, A.C., C.G. Okoli, I.C. Okoli, H.C, Nwigwe, and P.T.E. Ozoh, Assessment of the volume and disposal methods of spent engine oil generated in Nekede mechanic village, Owerri, Nigeria. Report and Opinio, 2010, 3(2)

[9] Iwegbue, C.M.A., E.S. Williams and G.E. Nwajei 2008. Characteristic levels of total petroleum hydrocarbon in soil profiles of automobile mechanic waste dump. Int. J. Soil Sci. 3, 48- 51

[10] Adelekan, B. A. and Abegunde, K. D. 2011. Heavy metals contamination of soil and groundwater at automobile mechanic villages in Ibadan, Nigeria. International Journal of the Physical Sciences 6(5),1045-1058

[11] Odoh R. Agbaji E.B. \& Kagbu J.A. 2011. Assessment of Trace Metals Pollution in Auto-Mechanic Workshop in Some Selected Local Government Area of Benue State, Nigeria International Journal of Chemistry 3(4), 78-88

[12] Pam, A. A., Sha'Ato, R and Offem, J.O. 2013. Contributions of Automobile Mechanic Sites to Heavy Metals in Soil: A Case Study of North Bank Mechanic Village Makurdi, Benue State, Central Nigeria J. Chem. Bio. Phy. Sci. 3(3), 23372347

[13] Cui, Y., Zhu, Y.G., Zhai, R., Huang, Y, Qiu, Y. and Liang, J. 2005. Exposure to metal mixtures and human health impacts in a contaminated area in Nanning, China. Environment. International. 31,784-790

[14] Gune, A., Alpasalan, M. and Inal, A. 2004. Plant growth and fertilizer. Ankara University of Agriculture publication. No: 1539, Ankara, Turkey.

[15] Nwachukwu, M.A., Feng, H. and Alinnor, J. 2010b. Assessment of heavy metal pollution in soil and their implications within and around mechanic villages; International Journal of Environmental Science Technology 7(2), 347-358

[16] Abdu, N. 2010. Availability, Transfer and balances of heavy metals in urban agriculture of West Africa. PhD. Thesis submitted to the Faculty of Organic Agricultural Sciences of the University of Kassel, Germany

[17] Ipeaiyeda, A.R., M. Dawodu and T. Akande, 2007, Heavy metals concentration of Topsoil and Dispersion in the vicinities of reclaimed auto-repair workshops in Iwo, Nigeria. Research Journal of Applied science, 2(II), 1106-1115.

[18] Akprido, S.O. and S.O. Asagba 2013. Quality Characteristics of Soil Close to the Benin River in the Vicinity of a Lubricating Oil Producing Factory, Koko, Nigeria. International Journal of Soil Science. 1-16

[19] Zheng, N., Wang, Q.C., and Zheng, D.M. 2007. Health risk of Hg, Pb, Cd, Zn, and $\mathrm{Cu}$ to the inhabitants around Huludao Zinc Plant in China via consumption of vegetables. Science of the Total Environment. 383:81-89.

[20] National Population Commission (NPC) 2006 'Population Census of the Federal Republic of Nigeria: Analytical Report at the National Level. Abuja: National Population Commission

[21] Folson, B.L., Lee, C.R., Bates, D.J., 1981. Influence of Disposal Environment on Availability and Plant Uptake of Heavy Metals in Dredged Material. Tech. Rep. El- 81-12 US Army, Washington DC.

[22] Bouyoucos, G. J., 1962. Hydrometer method improved for making particle size

[23] Anderson, S.E., and Ingram, J.S.I., 1989. Tropical Soil Biology and Fertility: A Handbook of Methods. C.A.B. International, Aberystwyth. 
[24] APHA 2005. Standard Methods for the Examination of Water and Wastewater. American Public Health Association, Washington, DC.

[25] Ideriah, T. J. K., Braide, S. A., Izonfuo, W. A. L., \& Adiukwu, P. U. 2004. Heavy metal contamination of soils along roadsides in Port Harcourt Metropolis, Nigeria. Bulletin of Environmental Contamination and Toxicology, 73, 67-70.

[26] Tukura, B.W., J.A. Kagbu. and G.E. Gimba. 2007. "Effects of pH and Total Organic Carbon (TOC) on distribution of trace metals in Kubanni dam sediments, Zaria, Nigeria". Science World Journal. 2 (3):1-6.

[27] Horckmans, L., Swennen, R. and Deckers, J. 2007. Retention and release of Zn and CD in spodic horizons as determined by $\mathrm{pH}_{\text {stat }}$ analysis and single extractions. Science of the Total Environment. 376, 86-89

[28] Sharma, R.C. and and Dogra, S. 2011. Characterization of the soils of lower Himalayas of Himachal Pradesh, India Nature Environment and Pollution Technology, Vol. 10, No. (3), 439-446.

[29] Lenntech, W.T. 2009. Chemical Properties, Health and Environmental Effects of copper. Lenntech Water Treatment and Purification Holding B.V. www.lenntech.com/periodic/elements/cu.htm

[30] European Commission Director General Environment, ECDGE (2010). Heavy Metals and Organic Compounds from Wastes Used as Organic Fertilizers. Final Rep., July. WPA Consulting Engineerslnc. Ref. Nr. TEND/AML/2001/07/20, pp. 73-74. http://ec.europa.eu/environment/waste/compost/pdf/hm finalreport.pdf.

[31] Ipeaiyeda AR, Dawodu M (2008). Heavy metals contamination of top soil and dispersion in the vicinities of reclaimed auto-repair workshops in Iwo Nigeria., Bullet . Chemistry Society Ethiopia 22(3), 339-348.

[32] Okoronkwo, N. E., Igwe, J. C. and Onwuchekwa, E. C. (2005). Risk and Health Implications of polluted soils for crop production. African J. of Biotechnol. 4(13),1521 - 1524.

[33] Davies, B.E. 1995. Lead. In: Heavy Metals in Soils, Second Edition (BJ Alloway, Ed.).Blackie, New York, pp. $206-223$.

[34] Agbein, J.O. 2002. Lead in a Nigerian savanna soil under long-term cultivation. Science of the Total Environment. 286,1-14

[35] Tack, F.M.G., Van Ranst, E. Lievens, C. and Vandenberghe, R.E. 2006. Soil solution Cd, Cu and Zn concentrations as affected by short time drying or wetting the role of hydrous oxides of Fe and Mn. Geoderma. 137,83-87

[36] Udousoro, I.I., I.U. Umoren, E.O. Asuquo, 2010. Survey of some Heavy Metal concentrations in selected soils in South Eastern parts of Nigeria. World Journal of Applied Science and Technology, 2(2),139-14.

[37] Kabata-Pendias, A., and Pendias, H. 2001. Trace elements in soils and plants. CRC Press, London.

[38] Wyszkowska, J. 2002. Soil Contamination by Chromium and its Enzymatic Activity and Yielding. Polish J. Environ. Stud., 11(1), 79-84.

[39] Ghosh, M and Singh, S.P. 2005. Comparative Uptake and Phytoextraction Study of Soil Induced Chromium by Accumulator and High Biomass weed Species. Appl. Ecol. Environ. Res., 3(2): 67-79. http://www.ecology.kee.hu.

[40] Curtis, L.R. and Smith, B.W. 2002. Heavy Metal in Fertilizers: Considerations in Setting Regulations in Oregon. Oregon Department of Agriculture, Salem, Oregon, p. 10.

[41] Ebong, G.A., Akpan, M.M. and Mkpene, V.N 2008. Heavy metal content of municipal and rural dumpsite soils and rate of accumulation by Carica papaya and Talinum triangulare in Uyo Nigeria. E-Journal of Chemistry, 5(2), $281-290$.

[42] Achi, M.M., Uzairu, A., Gimba, C.E. and Okunola. O.J. 2011. Chemical fractionation of heavy metals in soils around the vicinity of automobile mechanic workshops in Kaduna Metropolis, Nigeria. Journal of Environmental Chemistry and Ecotoxicology, 3(7), 184-194

[43] Reimann, C., Filzmoser, P., Garrett, R. and Dutter, R. 2008, Statistical Data Analysis explained. Applied environmental statistics with $R$. Wiley, $343 \mathrm{p}$.

[44] Sutherland, R.A., 2000. Bed sediment-associated trace metals in an urban stream, Oahu, Hawaii. Environ. Geol., 39, 611-37.

[45] Zhang, W., Feng, H., Chang, J., Jianguo, Q., Hongxia, X. and Lizhong, Y. 2009. Heavy metal contamination in surface sediments of Yantze intertidal zone: An assessment from different indexes. Environ. Pollut, 157 (5), 1533-1543

[46] Chatterjee, M., Silva, F. E. V., Sarkar, S. K., et al., 2007. Distribution and Possible Source of Trace Elements in the Sediment Cores of a Tropical Macrotidal Estuary and Their Ecotoxicological Significance. Environment International, 33, 346-356

[47] Fagbote, E.O. and Olanipekun, E.O. 2010. Evaluation of the status of Heavy Metal pollution of soil and plant (Chromolaena Odorata) of Agbadu Bitumen Deport Area, Nigeria. American - Eurasian Journal of Scientific Research, 5(4), 241- 248.

[48] Zhang, J. and C.L. Liu, 2002. Riverine composition and estuarine geochemistry of particulate metals in ChinaWeathering features anthropogenic impact and chemical fluxes. Estuar. Coast. Shelf S., 54,1051-1070. 
[49] WHO. 2010. Water for Health; Guideline for drinking water quality, incorporating $1^{\text {st }}$ and $2^{\text {nd }}$ Addenda to 3rd edition. Volume 1 recommendations.

\section{Biographical notes:}

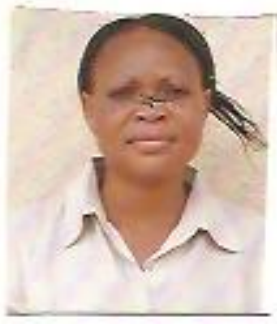

\section{Olayinka, Oluwafunmilayo 0.}

Olayinka, Oluwafunmilayo O. obtained her Masters in Analytical Chemistry (1999) and PhD in Industrial Chemistry (2010), both from University of Ibadan, Nigeria. She has worked at the Federal College of Wildlife Management, New Bussa, Nigeria. She is currently a lecturer in the Department of Environmental Management and Toxicology, Federal University of Agriculture, Abeokuta, Nigeria. Her research areas of interest analytical chemistry and environmental pollution and environmental analysis. She is a member of many scientific societies like Science Association of Nigeria, Chemical Society of Nigeria, Inst. of Chartered Chemist of Nigeria.

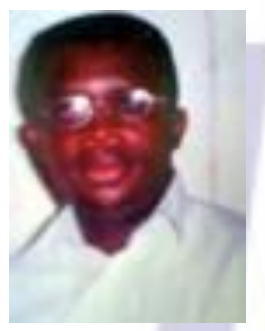

\section{Adedeji, Oludare $\mathbf{H}$}

Adedeji, Oludare H obtained his Masters in Geography (1998) and PhD in (Biogeography) (2008) both from University of Ibadan, Nigeria. He also obtained a Post Graduate Diploma (Natural Resources Management) from Faculty of GeoInformation Science and Earth Observation (ITC), University of Twente, Enschede, the Netherlands. He worked at the Olabisi Onabanjo University, Ago-Iwoye and presently in the Department of Environmental Management and Toxicology, Federal University of Agriculture, Abeokuta, Nigeria. He is actively involved in research related to resources management, environmental monitoring and geospatial mapping. He is a member of many scientific societies like Nigerian Geographical Association (ANG), Environmental and Behaviour Association of Nigeria (EBAN) and Soil Science Society of Nigeria. 